\title{
Antibacterial and antidiarrheal activity of Simarouba amara (Aubl.) bark
}

\author{
Hegde Veena ${ }^{1}$, Nagaraj Navya ${ }^{1}$, Gowda K Sandesh², Nayaka Boramuthi Thippeswamy ${ }^{1 *}$ \\ ${ }^{1}$ Department of P.G Studies and Research in Microbiology, Kuvempu University, Karnataka, India. \\ ${ }^{2}$ Niranthara Scientific Solutions Pvt. Ltd., Bengaluru, India.
}

\begin{tabular}{l}
\hline ARTICLE INFO \\
\hline Received on: 02/11/2018 \\
Accepted on: 16/03/2019 \\
Available online: 08/05/2019 \\
\hline Key words: \\
MIC, MBC, \\
castor-oil-induced diarrhea, \\
intestinal motility, charcoal \\
meal test, antidiarrheal index.
\end{tabular}

\begin{abstract}
The present study was conducted to determine the nutritional elements in Simarouba amara (Aubl.) bark aqueous extract (SAAE) by inductively coupled plasma optical emission spectrometry (ICP-OES) and the in vitro antibacterial activity against pathogens enterotoxigenic Escherichia coli, Salmonella typhi, Staphylococcous aureus, Klebsiella pneumoniae, and Pseudomonas aeruginosa by agar well diffusion, minimum inhibitory, and bactericidal concentration. Then, antidiarrheal effect was studied on castor oil-induced diarrhea in mice model. Recorded $\mathrm{Mg}>\mathrm{Fe}$ $>\mathrm{Cu}>\mathrm{Zn}$ elements in SAAE invariably found to be effective against Gram-positive and Gram-negative pathogens. Effective concentration of bark showed the zone of inhibition against enterotoxigenic E. coli $(200 \mathrm{mg} / \mathrm{ml})$, S. typhi and $S$. aureus $(300 \mathrm{mg} / \mathrm{ml})$, and P. aeruginosa and K. pneumonia $(100 \mathrm{mg} / \mathrm{ml})$. The standard ratio between minimum inhibitory concentration (MIC) and minimum bactericidal concentration (MBC) was meticulously recorded "one" against all pathogens, which confirms the bactericidal property. Results in mice model prominently showed that SAAE significantly $(p<0.05)$ reduced the frequency and number of diarrheal episodes, intestinal fluid accumulation, and intestinal transit time in dose-dependent manner. Inordinate delay in charcoal movement in the intestine positively confirmed the antispasmodic effect by reducing propulsive movement. Confirmed findings in this study naturally suggested that SAAE could be an effective antibacterial and antidiarrheal formulation.
\end{abstract}

\section{INTRODUCTION}

The normal flora of a human is limited to certain area of the organized body, including the skin, mouth, large intestine, and the vagina (Arunlakshana and Schild, 1959) may act as opportunistic pathogens in injured or immunocompromised host. According to World Health Organization (WHO), 12 families of bacteria pose the broadest threat to human health. Furthermore, these infectious organisms were divided into three ideologic categories based on the urgency of need for new antibiotics: critical, high, and medium priority. The most critical group appropriately includes multidrug resistant bacteria such as Acinetobacter, Pseudomonas, and various Enterobacteriaceae, including Klebsiella, Escherichia coli,

"Corresponding Author

Nayaka Boramuthi Thippeswamy, Department of P.G Studies Research in Microbiology, Kuvempu University, Shivamogga, India.

Email:nbtmicro@gmail.com
Serratia, and Proteus sp., creates a considerable threat in hospitals, nursing homes, and among patients, whose care depends upon specialized devices like ventilators and blood catheters. They can cause severe and often deadly infections, such as bloodstream infections, diarrhea, and pneumonia. These become resistant to a massive number of preventive antibiotics, including carbapenems and third generation cephalosporins, which are available for treating multi-drug resistant bacteria. Among bacterial diseases, diarrhea remains a second leading cause of death among children under the age of five globally. Nearly, one in five children death about 1.5 million each year has been recorded. Oral rehydration solution and rotavirus vaccination recommendations by WHO in the developing countries have undoubtedly resulted decreased number of deaths by two-third, but in reality, figures are still high. As such, the remarkable progress is being gently made and much more remains yet to be done economically. In major, diarrheal disease is due to enteropathogens, diarrheagenic $E$. coli remain a most common causative agent in developing countries; Enterotoxigenic E. coli (ETEC), enteroaggregative E. coli, encroaching pathogens like 
Shigella spp., Campylobacter and Salmonella spp. Antimotility agents (loperamide), antisecretory agents (racecadotril), and adsorbents (diosmectite) possess dreadful side effects in children. In consequence, traditional medicines become a deliberate choice of equitable treatment. Centralized governments in India, China, and South Africa are seamlessly incorporating traditional, a less side effective health care practices into their national scheme to overcome the problems. Accomplished work on plant products in the recent years reliably provided the source to develop naturally a potent formulation to encounter diarrhea and other illness with positively enhancing the immune system (Ismail and Asad, 2009). Similarly, Simarouba amara (Aubl.), which is a native plant species of Simaroubaceae family, has been used as a natural medicine in tropics. The family includes 32 genera and more than 170 species of trees. Simarouba amara (Aubl.) is a medium-sized tree, indigenous to the Amazon Rainforest and other tropical areas in Mexico, Cuba, Haiti, Jamaica, and Central America. French explorers fortunately discovered and found that the ancient Indian tribes in the Guyana rainforest used S. amara (Aubl.) bark as an effective treatment for dysentery and malaria. In Brazil, the majestic tree is traditionally called negrito or "dysentery bark." The excellent tonic of bark is conventionally used to wash skin sores and to treat dysentery, diarrhea, stomach and bowel disorders, hemorrhages, and internal bleeding. The active constituent "quassinoids," which belongs to the triterpene chemical family, have been credibly reported for vast spectrum of biological activities, such as antitumor, antimalarial, antiviral, effective insecticide and feeding deterrent (Khan et al., 1996; Polonsky et al., 1978; Taylor, 2003; Wright et al., 1988) antiparasitic, and herbicidal activities. Dehydroglucarubinone possesses antineoplastic activity by inhibiting DNA polymerase activity destructing cancer cell membrane system. It was found precisely that SA bark is effective in treatment for gastric ulcer and hepatic damage in mice (Maranhão et al., 2014A). Quassinoid containing fraction of the stem has strikingly shown amebicidal and antimalarial activity against Entameoba histolytica and Plasmodium falciparaum (Maranhão et al., 2014A). In the present study, the nutritional elements in S. amara (Aubl.) bark aqueous extract (SAAE), antibacterial activity against human pathogens, and antidiarrheal activity of SAAE was scientifically investigated in mice via an oral route.

\section{MATERIAL AND METHODS}

\section{Chemicals}

Simarouba amara (Aubl.) bark was kindly provided by Niranthara Scientific Solutions Pvt Ltd. Bengaluru, Karnataka, India, Castor oil (Cremophor ${ }^{\circledR}$; Himedia), Loperamide Hydrochloride Capsules IP (Eldoper ${ }^{\circledR}$; Microlabs Ltd.), Atropine sulfate monohydrate (Himedia), Charcoal-activated powder, L.R, (Himedia), and Gum Acacia powder (Himedia). Eterotoxigenic test organisms used: E. coli (ETEC H10407 $\mathrm{LT}^{+}, \mathrm{ST}^{+}$) (MTCC 723), Salmonella enteric serovar Typhi (MTCC 733), Staphylococcous aureus (MTCC 96), Klebsiella pneumoniae (MTCC109), and Pseudomonas aeruginosa (MTCC741). Stock cultures were maintained on nutrient agar slants at $4^{\circ} \mathrm{C}$ and sub cultured in nutrient broth at $37^{\circ} \mathrm{C}$ prior to each antimicrobial test.

\section{Preparation of bark extract}

Simarouba amara (Aubl.) bark aqueous extract was prepared as previously described method (Maranhão et al., 2014 B). Briefly, 10-g bark powder was extracted with $100-\mathrm{ml}$ distilled water $(10: 100 \mathrm{w} / \mathrm{v})$ as solvent by boiling for 15 minutes. After cooling, the extract was filtered through no. 1 Whattman filter paper and obtained aqueous extract was concentrated in lyophilizer and stored in air tight vials at $4^{\circ} \mathrm{C}$. After drying, percentage of yield was determined.

\section{Animals}

Healthy Swiss albino female mice $(20-25 \mathrm{~g}$ b. w) were used for the experiment. Mice were acclimatized for 7 days to laboratory conditions for minimizing any nonspecific stress. Animals were fed with a standard commercial pellet feed and received clean drinking water ad libitum. The temperature varied between $28^{\circ} \mathrm{C}$ and $30^{\circ} \mathrm{C}$ and relative humidity of about $56 \%-60 \%$ with 12-hour light-dark cycle. The animals were handled according to Institutional Animal Ethics Committee (IAEC) standard guidelines in experiments (NGSMIPS/IAEC/MARCH-2018/103).

\section{Determination of nutritional elements in plant extract by ICP- OES}

Simarouba amara (Aubl.) bark aqueous extract (lyophilized) was subjected for nutritional element analysis by inductively coupled plasma optical emission spectroscopy (ICPOES) method (Shao and Bian, 2002). Briefly, 0.25-g SAAE was digested with 5-ml concentrated nitric oxide $\left(\mathrm{HNO}_{3}\right)$ and left for 12 hours. After the pre-digestion for 12 hours, sample was digested at $180^{\circ} \mathrm{C}$ on a hot plate till the nitric acid about to evaporate. Furthermore, $5 \mathrm{ml}$ of mixture of di-acids (nitric oxide and perchloric acid, 10:2) was added to the sample and digested until the sample become transparent. Sample was cooled at the room temperature and filtered through filter paper in volumetric flask $(25 \mathrm{ml})$ and volume was made up with $2 \% \mathrm{HNO}_{3}$. Meanwhile blank without the sample was also processed in the similar manner and elements $(\mathrm{Mg}, \mathrm{Cu}, \mathrm{Fe}$, and $\mathrm{Zn}$ ) were analyzed through ICP-OES (Perkin Elemer-5300 V).

\section{Determination of antimicrobial activity by well diffusion method}

Antimicrobial activity of bark aqueous extract was evaluated by well diffusion method (Bennett et al., 1996). Bacterial cultures were adjusted to $0.5 \mathrm{McFarland}$ turbidity standards. Equal volume $(100 \mu \mathrm{l})$ of different concentration of reconstituted bark extract $(100,200,300,400$, and $500 \mathrm{mg} / \mathrm{ml})$, and standard antibiotics (Co-Trimaxazole, Ampicillin, and streptomycin; $1 \mathrm{mg}$ / $\mathrm{ml}$ ) were used. Furthermore, the zone of inhibition $(\mathrm{mm})$ was measured against each pathogen.

\section{Determination of MIC and MBC by broth dilution method}

Two-fold serial dilutions were made with Muller Hinton broth from reconstituted bark extract $(10-1.25 \mathrm{mg} / \mathrm{ml})$ and $100 \mu \mathrm{l} /$ well from all dilutions used. Nearly, $100-\mu 1$ bacterial inoculum $\left(10^{5}\right.$ $\mathrm{CFU} / \mathrm{ml}$ ) was added to respective wells containing the test plant extract except negative control and mixed and incubated for 24 hours. After incubation, 50- $\mu$ 1 MTT dye [3-(4, 5 -Dimethylthiazol- 
2-yl)-2, 5-diphenyl tetrazolium bromide; yellow dye; $0.020 \mathrm{mg}$ / $\mathrm{ml}$ ] was added to each well and incubated for 30 minutes at $37^{\circ} \mathrm{C}$. The viable bacterial cells in the well change the yellow MTT dye to blue color. In assay, the lowest concentration at which no visible colour change was observed and that was considered as minimum inhibitory concentration (MIC) (Elena et al., 2003). Similarly, the minimum bactericidal concentration (MBC) was determined by sub culturing the test dilution on fresh solid medium and further incubated at $37^{\circ} \mathrm{C}$ for $18-24$ hours. The lowest concentration of MIC tubes with no visible bacterial growth on solid medium was considered as MBC (Bennett et al., 1996; Wright et al., 1988).

\section{Effect of SAAE on castor oil-induced diarrhea in mice}

The experiment was performed according to previously described method (Degu et al., 2016). Briefly, 25 mice were fasted for 18 hours and randomly divided into five groups of five mice each. Further, mice in group I (control) received sterile water 1 $\mathrm{mL} / 100$ g p.o., group II (positive control) received loperamide 3 $\mathrm{mg} / \mathrm{kg}$ p.o., and mice in groups III, IV, and V SAAE $(100,200$, and $300 \mathrm{mg} / \mathrm{kg}$, p.o.) in single dose, respectively. After 60 minutes, $0.5-\mathrm{ml}$ castor oil was given orally to animals in all groups. Each animal was placed in individual cage, whose floor was lined with blotting paper and changed every hour for observation up to 4 hours. While observing, time of onset of diarrhea, total number of stools, and number of wet feces excreted by animals were recorded, and the percentage of inhibition of defecation was calculated by using the following formula:

$$
A=\text { Average number of wet feces in control group }
$$$$
B=\text { Average number of wet feces in test group. }
$$

\section{Effect of SAAE on gastrointestinal transit}

This was evaluated by charcoal meal marker diet test (Brijesh et al., 2009; Degu et al., 2016; Sharma et al., 2009). Swiss Albino mice were randomly divided into five groups of five mice each, fasted for 18 hours with free access to water. The group I (control) mice were administered with sterile water $1 \mathrm{ml} / \mathrm{kg}$ p.o., group II (positive control) with atropine sulfate $2.5 \mathrm{mg} / \mathrm{kg}$ i.p., and groups III, IV and V with SAAE 100, 200, and $300 \mathrm{mg} / \mathrm{kg}$, p.o. in single dose, respectively. Thirty minutes after drug administration, mice in all groups were fed with $1-\mathrm{ml}$ charcoal meal by gastric gavage (10\% activated charcoal suspension in $5 \%$ gum acacia) as a food tracer. All mice were sacrificed by cervical dislocation after 30 minutes and dissected longitudinally. Total length of small intestine and charcoal movement from pylorus to caecum was measured by calibrated ruler. Percentage of inhibition and peristalsis index was expressed by using the following formula:

$A=$ Distance travelled by charcoal meal in control group (cm)

$B=$ Distance travelled by charcoal meal in treated group (cm).

\section{Effect of SAAE on castor oil-induced enteropooling}

Mice were randomly divided into five groups of five mice each, fasted for 18 hours with free access to water. The group I (control) mice were treated with sterile water $1 \mathrm{ml} / \mathrm{kg}$ p.o., group II (positive control) with loperamide $3 \mathrm{mg} / \mathrm{kg}$, p.o., and the groups III, IV, and V with SAAE 100, 200, and $300 \mathrm{mg} / \mathrm{kg}$, p.o. in single dose, respectively. After 30 minutes, mice in groups were challenged with $1 \mathrm{ml}$ of castor oil orally. After 30 minutes, mice were sacrificed by cervical dislocation; small intestine was excised from pylorus to caecum. Immediately, small intestine was weighed. Contents of intestine were collected by milking into a graduated tube and the volume was measured. Eventually small intestine was reweighed, the difference between full and empty intestine was calculated. Percentage of inhibition of fluid accumulation and percentage inhibition of intestinal content was determined (Ngo-Teke et al., 2010).

MVICC $=$ Mean volume of intestinal content in control group

MVICT $=$ Mean volume of intestinal content in treated group

$A=$ Mean weight of intestinal content in control group

$B=$ Mean weight of intestinal content in treated group.

\section{In vivo antidiarrheal index}

Antidiarrheal index was expressed after cumulating the data according to the formula:

In vivo antidiarrheal Index (ADI in vivo $)=$

$D_{\text {fra }}(\%)$ is the delay in defecation time (minutes), $G_{\mathrm{MT}}$ $=$ Gut meal travel reduction (as \% of inhibition), and $P_{\mathrm{frq}}=$ the reduction in the number (frequency) of stools (Degu et al., 2016).

\section{Statistical analysis}

Analysis was performed using Graph Pad Prism version 5.0 (GraphPad Software, La Jolla, CA). A result in antibacterial activity was a minimum of three repetitions and analyzed using standard error mean. In antidiarrheal activity, difference between groups was analyzed with one way analysis of variance (ANOVA) and $p<0.05$ was considered as statistically significant. Error bar represents mean with standard deviation.

\section{RESULTS AND DISCUSSION}

Present task to carefully develop a convenient antibiotic is a time-dependent process and may severely hinder the effective treatment option. Therefore, attempts must be wisely directed toward the necessary development of the effective natural, nontoxic drug for restorative treatment (Chandra, 2013; Kang et al., 2011). Various published findings on secondary metabolites in distinct plants delivered the rich resource to sufficiently develop a novel compound to encounter drug-resistant pathogenic bacteria and diarrhea causing organisms (Khan et al., 2012).

\section{Nutritional elements in SAAE by ICP-OES}

The medicine value of a plant depends on its macro and trace elements. Nitrogen, phosphorous, magnesium, potassium, calcium, sulphur, carbon, oxygen, and hydrogen are macro elements, whereas iron, copper, chlorine, zinc, boron, and molybdenum are considered as trace elements. In our ICP-OES element analysis experiment, SAAE showed higher amount of magnesium $(3240.6 \mu \mathrm{g} / \mathrm{g})$, iron $(318.4 \mu \mathrm{g} / \mathrm{g})$, copper $(315.3 \mu \mathrm{g} / \mathrm{g})$ than zinc $(10.1 \mu \mathrm{g} / \mathrm{g})$ (Table 1). These nutritional elements have complex interaction with in a system and important to prolong the normal metabolism (Alberts et al., 1995; Raj et al., 2017). Moreover, certain trace elements are low in human body and are essential for normal functions. $\mathrm{Na}^{+}, \mathrm{K}^{+}$, and other macro elements are playing a major role in osmotic pressure and acid base 
Table 1. Available nutritional elements in SAAE by ICP-OES method.

\begin{tabular}{lcccc}
\hline \multirow{2}{*}{ Test sample } & $\mathbf{C u}^{2+}$ & $\mathbf{M g}^{2+}$ & $\mathbf{F e}^{2+}$ & $\mathbf{Z n}^{2+}$ \\
\cline { 2 - 5 } & \multicolumn{4}{c}{$(\boldsymbol{\mu g} / \mathbf{g})$} \\
\hline SAAE & 315.5 & 3240.6 & 318.4 & 10.1 \\
\hline
\end{tabular}

balance. But, $\mathrm{Mg}^{2+}$ deficiency results in increased excitability of the nervous system and hence key element for proper functioning of central nervous system. Then, $\mathrm{Fe}^{2+}$ is a carrier of hemoglobin and an active site of many enzymes. In contrast, $\mathrm{Zn}^{2+}$ and $\mathrm{Cu}^{2+}$ are important for immunity and involved in acceleration of healing of damaged tissue, resistance over infections (Kiela et al., 2016; Qing-hua et al., 2012; Zeng et al., 2001). Thus, the study of elements in our bark extracts reveals the mechanism involved in its antibacterial and antidiarrheal property.

\section{Antibacterial activity by well diffusion method}

Novel antibiotics slow down the possible infection by disrupting the complex synthesis of the peptidoglycan layer constructing the bacterial cell wall. Similarly, phenols, flavonoids, and alkaloids kill the infectious microorganisms. Notable core lipophilic active component Curcumin-I was reported in Curcuma longa as a polyphenol. This leads to membrane leakage in gram positive (Methicillin-resistant S. aureus and Enterococcus fecalis) and gram negative (E. coli and Pseudomonas aeruginosa) bacteria. Meanwhile, the curcumin-I showed bactericidal activity at minimum load $\left(10^{4} \mathrm{CFU} / \mathrm{ml}\right)$ and exerted bacteriostatic mechanism at maximum load $\left(10^{6} \mathrm{CFU} / \mathrm{ml}\right)$ of organisms (Aqil et al., 2005; Tyagi et al., 2015). In the present study, SAAE appreciably reduces the intended load of $P$. aeruginosa and K. Pneumoniae $(100 \mathrm{mg} / \mathrm{ml})$, ETEC H10407 (200 mg/ml), and S. typhi and S. aureus $(300 \mathrm{mg} / \mathrm{ml})$ (Fig. $5 \mathrm{~A}-\mathrm{Y}$ ). Meanwhile, standard antibiotic co-trimaxazole is mean for treating $E$. coli infections but shown moderate zone of inhibition against ETEC and shown maximum antibacterial activity $S$. aureus and minimum or nil at both $K$. pneumonia and $P$. aeruginosa. Similarly, amphicilin had shown moderate activity against $S$. tyhpi and maximum against $S$. aureus. But, streptomycin a broad spectrum antibiotic had shown antibacterial activity against all test pathogens. Comparative results in our study had shown that SAAE can compete with the tested synthetic antibiotics. Since as reported explained findings on active component in species of Simaroubaceae family suggested the inhibition of protein synthesis and aerobic respiration in microorganisms. Likely results observed in our study (agar well diffusion method) positively obey the stated mechanism (Table 2) (Valle et al., 2015). Moreover, the presence of $\mathrm{Zn}^{2+}, \mathrm{Mg}^{2+}, \mathrm{Cu}^{2+}$, and $\mathrm{Fe}^{2+}$ in SAAE extract increased its antibacterial efficacy. According to the studies, $\mathrm{Zn}$ binds to the membrane of organism and interferes in cell division by extending the lag phase in cell cycle (Lemire et al., 2013). Similar effect was observed in $\mathrm{Mg}^{2+}$ and $\mathrm{Ca}^{2+}$ in antibiotic resistant $S$. aureus eradication. Both were involved in membrane disruption and kill the $S$. aureus at stationary phase (Arakha et al., 2015; Weaver et al., 2014; Xie and Yang, 2016).

\section{MIC and MBC}

SAAE typically exhibited the bactericidal nature by showing precisely MBC/MIC ratio " 1 ." The used concentration in MIC and MBC appeared high against selected pathogens (Banfi et al., 2003; Nemeth et al., 2015) (Table 2), but the beneficial activity of concentrated extracts is unrelated to their respective dry weight. Observed result in studies, for instance clove $(95 \mathrm{mg} /$ $\mathrm{ml})$, guava $(122 \mathrm{mg} / \mathrm{ml})$, and garlic $(133 \mathrm{mg} / \mathrm{ml})$ extracts, showed alike antimicrobial activity patterns (Satyajit and Lutfun, 2007). Considered results in our present study represent an agreement with several previous findings, the gracious presence of cardiac glycosides, terpenoids, flavonoids and phenols accurately reflect the membrane leakage, chief hindrance in protein synthesis and aerobic respiration in pathogens.

\section{Effect of SAAE on castor oil-induced diarrhea in mice}

Castor oil is laxative agent in which ricinoleic acid, a hydroxylated fatty acid, released from castor oil by intestinal lipases (Tunaru et al., 2012). Consequently, it activates an EP3 prostanoid receptor that mediates the elevated production of prostaglandins, nitric oxide, which produces local irritation, inflammation, net secretion of water, and electrolytes in lumen. Thoroughly documented fact on infectious diarrhea confirms the multifactorial and series of cascading reactions, fundamental imbalance in electrolyte absorption (active $\mathrm{Na}^{+}$and $\mathrm{K}^{+}$), and smooth muscle contractility in the intestine via inhibiting $\mathrm{Na}^{+}-\mathrm{K}^{+}$ ATPase in the small intestine (Enzo, 2006). In the present study, result showed, the standard dose of castor oil administered was sufficient to naturally evoke the diarrhea. SAAE was assuredly found to be effective in a dose-dependent 100, 200, and $300 \mathrm{mg} /$ $\mathrm{kg} \mathrm{b}$. w manner. At an active dose of $300 \mathrm{mg} / \mathrm{kg}$, bark extract reduced the number of wet feces and progressively extended the latency phase up to 195.33 minutes and onset of diarrheal episode (Fig. 1) significantly $(p<0.05)$. Overall at $300 \mathrm{mg} / \mathrm{kg}$, bark extract reduced $(42.85 \%)$ the castor oil-induced diarrhea compared to reference drug loperamide (33.42\%). The findings in this study are in line with previous likely studies and SAAE acts like non-steroidal anti-inflammatory drug. Consequently, it inhibits the prostaglandin production and slows down the diarrhea.

Table 2. Antibacterial activity of SAAE against infectious bacterial pathogens; "0": No inhibition zone was observed, Std: Co-Tr: Co-Trimaxazole, Am: Amphicilin St: Streptomycin, ETEC: Enterotoxigenic E. coli $\mathrm{H} 10407\left(\mathrm{LT}^{+}, \mathrm{ST}^{+}\right)$, S. typhi, K. pneumoniae, Pseudomonas aeruginosa, and S. aureus

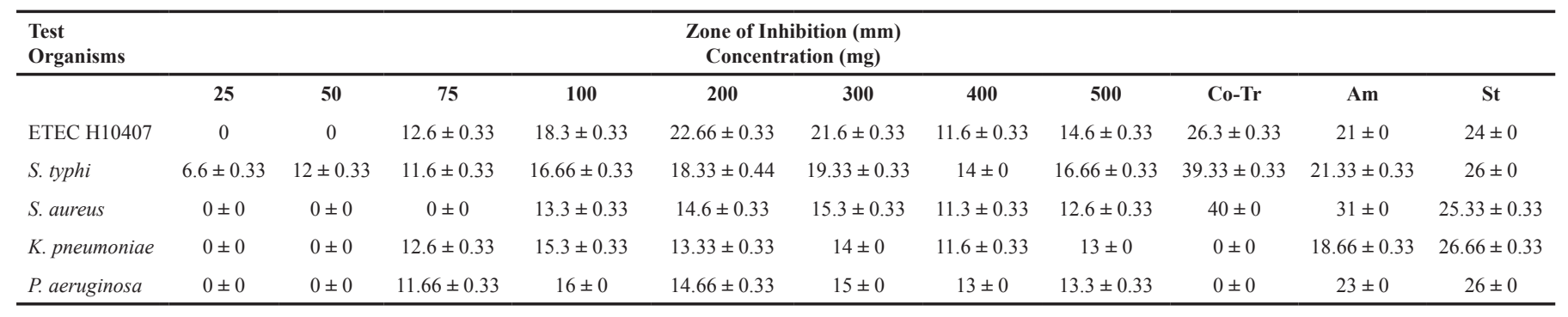


Table 3. MIC and MBC of SAAE against infectious bacterial pathogens

\begin{tabular}{lcccc}
\hline \multirow{2}{*}{ Organism } & MIC & \multicolumn{1}{c}{ MBC } & \multirow{2}{\text{MBC/MIC}}{\begin{tabular}{c} 
Activity \\
\cline { 2 - 3 } ratio
\end{tabular}} & \\
\hline ETEC & 10 & 10 & $1: 1$ & Bactericidal \\
S. typhi & 10 & 10 & $1: 1$ & Bactericidal \\
S. aureus & 5 & 5 & $1: 1$ & Bactericidal \\
K.pneumoniae & 10 & 10 & $1: 1$ & Bactericidal \\
P. aeruginosa & 5 & 5 & $1: 1$ & Bactericidal \\
\hline
\end{tabular}

SAAE produced significant reduction at a lower dose $(300 \mathrm{mg} / \mathrm{kg})$ compared to previously reported antidiarrheal plant extract like methanol and chloroform leaf extract of Croton macrostachyus hochsht. ex Del. produced overall decline in castor oil-induced diarrhea at 300,400 , and $500 \mathrm{mg} / \mathrm{kg}$ and aqueous extract at 1,000 $\mathrm{mg} / \mathrm{kg}$ (Degu et al., 2016). Investigative findings on tannins, terpenoids, flavonoids, and other secondary metabolites suggested their opioid like mechanism in silencing the direct action on secreto-motor neuronal pool in the submucosal plexus. This results in the reduced fluid secretion in a small intestine and dried, harder stool in the large intestine.

\section{Effect of SAAE on gastrointestinal motility test}

Ricinoleic acid is gently released by the castor oil absorbed body via intestinal mucosa where prostaglandin EP3 receptors are present. This acts upon G-proteins and sequentially on muscle cells of the intestine, which naturally induces pain. Further, it is responsible for increased propulsive movement. Mainly muscarinic acetylcholine receptors M1 and M2 preferentially bind to Gq protein and Gs/Gi protein, which act on secondary messengers like up regulation of phospholipase, down regulation of cyclic adenosine monophosphate (cAMP),

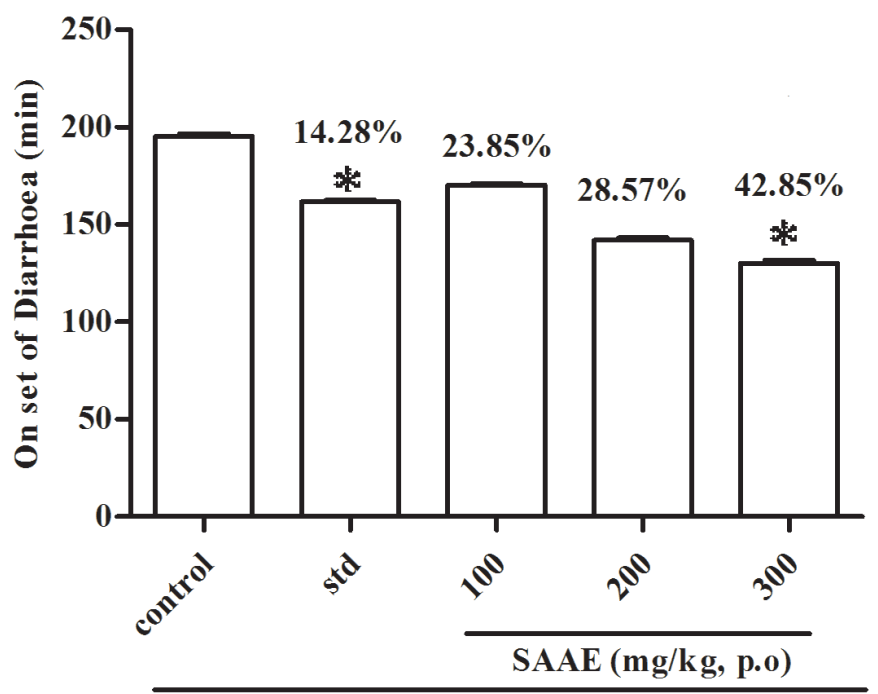

Castor Oil Induced Diarrhoea

Figure 1. SAAE extract administration reduced the onset of diarrhea (min) in dose-dependent manner and loperamide $(3 \mathrm{mg} / \mathrm{kg}, \mathrm{p} . \mathrm{o})$ used as standard. Data were expressed as Mean $\pm \mathrm{SD}(n=5)$. Analysis was performed with One-Way ANOVA. The asterisk* stands for $p<0.05$ compared with model control (castor oil-induced diarrhea). Superscripts were the protection percentage of diarrhea in each dosage group. and important physiological role in properly regulating the peristaltic movements of the gut (Brown and Taylor, 1996). In our completed study, SAAE has significantly lessened the gastrointestinal motility or charcoal meal movement accordance with dose $(100,200$, and $300 \mathrm{mg} / \mathrm{kg}$ b.w) dependent manner ( $p<$ 0.05 ) (Fig. 2). At the dose $300 \mathrm{mg} / \mathrm{kg}$, bark extract has sufficiently reduced the peristaltic movement and decreased intestinal spasms by inhibiting the parasympathetic activity. Standard drug atropine and other anticholinergics act as an "encephalin"worthy antagonist on muscarinic receptors and decrease the intestine motility by inhibiting acetylinecholine. Further helps in delaying of intestine peristaltic movement and gastric emptying (Arunlakshan and Schild, 1959; Maddison et al., 2002). Peerreviews on studies of flavonoids and polyphenols have describe the able results to inhibit the prostaglandin EP3 activated muscle contraction and inhibiting the unconditional release of prostaglandins and autocoids (Brijesh et al., 2009; Dosso et al., 2011). Accordingly, results in our experiment revealed the possible role in gastrointestinal motility. SAAE is enriched with flavonoids, phenols and $\mathrm{Ca}^{2+}$ was acts as better antagonist and reduces the intestinal movement via calcium sensing receptor (CaSR) activation (Favus et al., 1981). Moreover, $\mathrm{Ca}^{2+}$ stimulates epithelial cell differentiation and maturation, increased gastrinhormone and $\mathrm{Ca}^{2+}$ dependent CaSR activation modulates the intestine fluid secretion by inhibiting cyclic nucleotides [cAMP/ cyclic guanosine monophosphate (cGMP)] and increases the nutrient contact time for absorption by intestine villi (Kirchhoff and Giebel, 2006). The fact of malabsorption and micronutrients deficiency prolongs the diarrhea and clinical damage. Hence, the Indian Academy of Pediatrics suggests the micronutrients uptake

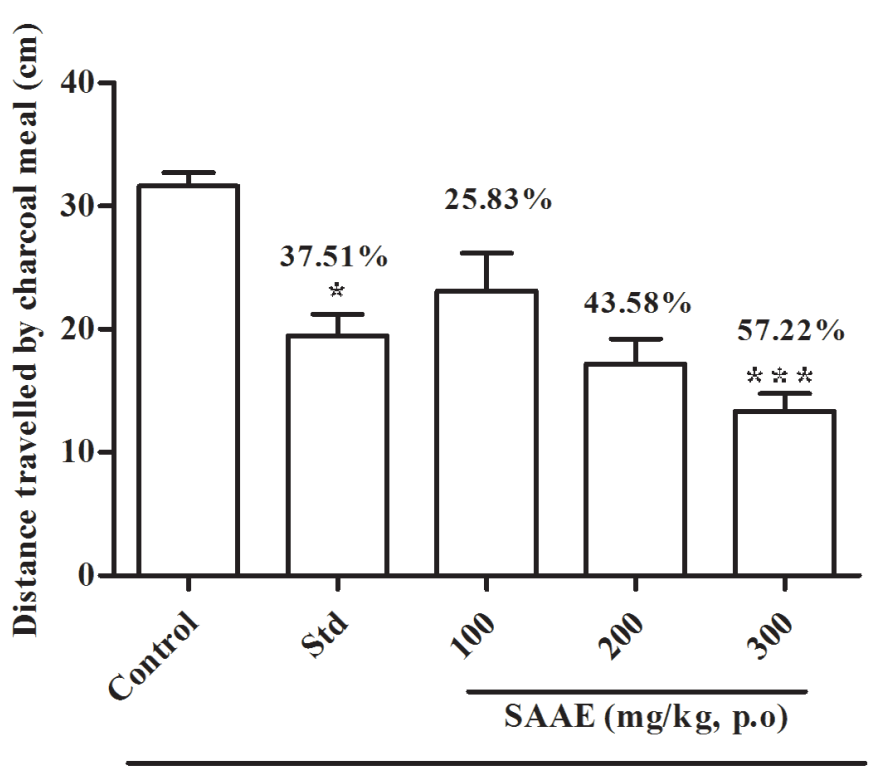

Castor Oil Induced Diarrhoea

Figure 2. SAAE administration reduced the charcoal movement in small intestine in dose-dependent manner and atropine sulfate $(2.5 \mathrm{mg} / \mathrm{kg}$, i.p) used as standard. Data were expressed as Mean $\pm \mathrm{SD}(n=5)$. Analysis was performed with One-Way ANOVA. The asterisk* stands for $p<0.05$ compared with model control (castor oil-induced diarrhea). Superscripts were the percentage of inhibition of gastro intestinal motility in each dosage group. 
for 2 weeks in treatment of diarrhea along with rehydration therapy. Major nutrients are folic acid (5 mg day 1, then $1 \mathrm{mg} /$ day), zinc (2 $\mathrm{mg} / \mathrm{kg} /$ day), and copper $(0.3 \mathrm{mg} / \mathrm{kg} /$ day $)$, and vitamin A, magnesium $0.2 \mathrm{ml} / \mathrm{kg} /$ dose twice, and $3 \mathrm{mg} / \mathrm{kg} /$ day of iron (Bhutta et al., 2000). The folic acid, copper, selenium, vitamin $\mathrm{A}$, and zinc help in restoring small intestine damage (Giannattasio et al., 2016). This favorable result clearly supports the proper evidence to its local name "dysentery bark" and antidiarrheal property meaningfully compared with standard drug loperamide and atropine sulfate.

\section{Effect of SAAE on castor oil-induced enteropooling}

In our attentive study, SAAE was convincingly showed antidiarrheal property by reducing intestinal fluid accumulation at doses 100, 200, and $300 \mathrm{mg} / \mathrm{kg}$ significantly $(p<0.05)$ (Fig. 3). In established physiology, endogenous nitric oxide is proabsorptive and it influence on enteric nervous system, suppress the prostaglandin formation, and opening of basolateral $\mathrm{K}^{+}$channels. Moreover, nitric oxide synthase inhibitors (e.g., l-NG-nitro-arginine methyl ester, 1-NAME; NG-monoethylarginine, NMMA; NG-nitro-arginine, NNA; 7-nitroindazole; s-methylisothiourea, SMT etc.) lead to net secretion by generating prostaglandin in animal model such as mice, rats, guinea pigs, rabbits, and dogs (Adeyemi and Akindele, 2008). Hence, in the presence of a laxative agent, nitric oxide synthase produced more elevated concentrations that evoke net secretion. SAAE reduced the fluid accumulation efficiently at $300 \mathrm{mg} / \mathrm{kg}$ by inhibiting the nitric oxide, and consequently prostaglandin E2 production. Alkaloids (Enzo, 2006), flavonoids (Hamalainen et al., 2011; Medina et al., 1997), and terpenoids (Maciel et al., 2000) inhibit the intestinal motility and hydroelectrolytic secretions, whereas, tannins denature functional proteins in the intestinal mucosa by

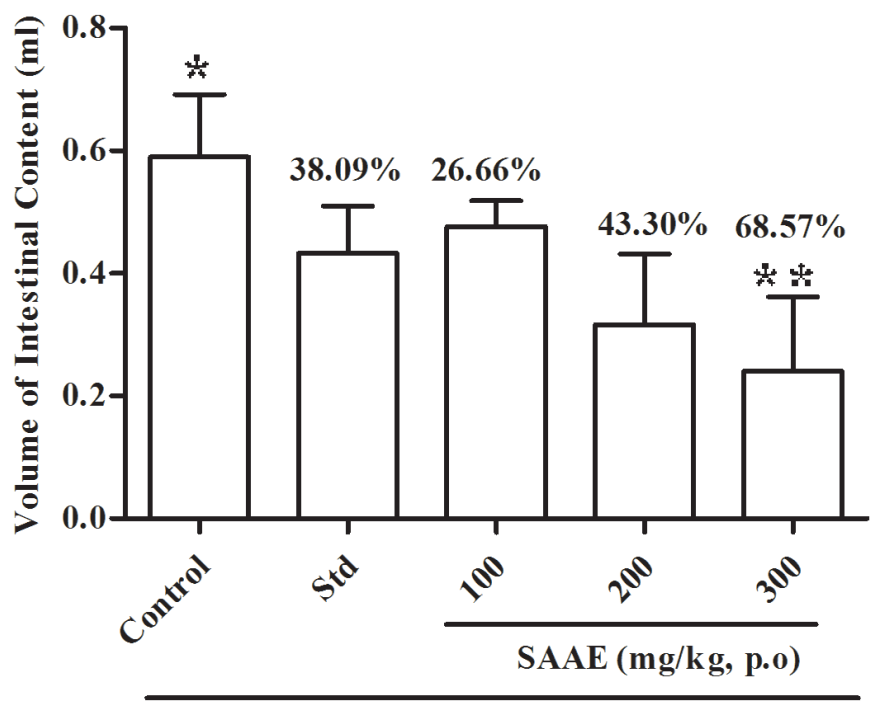

Castor Oil Induced Diarrhoea

Figure 3. SAAE administration reduced the intestinal fluid accumulation in dose-dependent manner and loperamide (3mg/kg, p.o) used as standard. Data were expressed as Mean $\pm \mathrm{SD}(\mathrm{n}=5)$. Analysis was performed with OneWay ANOVA. The asterisk* stands for $p<0.05$ compared with model control (castor oil-induced diarrhea). Superscripts were the percentage of inhibition of accumulation fluid content in small intestine in each dosage group. forming protein tannates, which adequately reduces the fluid secretion by inhibiting nitric oxide synthase (Almieda et al., 1995; Tripathi, 2008; Yadav and Tangpu, 2007). Potentially, tannins are involved in silencing the EP3 receptor on mucosal layer, which activate calcium pumping system (which induces the muscle relaxation). Most of terpenoids like abietic acid and steroids like phytosterols reported for the inhibition of prostaglandin E2 production, which reregulates the propulsive movement of gut (Awad et al., 2004). Moreover, synergistic action of terpenoid and flavonoid acts against inflammation and counteracts the complex NO synthesis. At present, two classes of antidiarrheal synthetic drugs; opioids, adsorbent and bulking agent are preferentially used for treatment. Loperamide is an opioid, a mainstay in successful treatment, which binds to $\mu$-receptor on neurons in the sub mucosal neural plexus of the small intestine. The instantaneous action on $\mu$-receptor prolongs the transit time and anti-motility action enhances segmental contraction of the colon, thereby inhibiting small intestine contraction colonic action. SAAE remarkably exerted the therapeutic effect with $60.46 \%$ protection percentage. Taking everything into account, the recorded available secondary metabolites and nutrients $(\mathrm{Mg}, \mathrm{Fe}, \mathrm{Cu}$, and $\mathrm{Zn})$ of SAAE may increases the $\mathrm{Na}^{+}-\mathrm{K}^{+}$ATPase enzyme activity by reducing the concentration of nitric oxide in small intestine. $\mathrm{Mg}^{2+}$ and $\mathrm{Cu}^{2+}$ ions are fundamental component of the body, which help in stabilizing the enzymes and strike out the cramps of muscle during its deficiency. $\mathrm{Cu}^{2+}$ ions are critical for metalloenzymes such as superoxide dismutase, which neutralizes the potential damaging superoxide anions, nitric oxide radical, oxidative stress, and oxidative damage (Ighadaro and Akinloye, 2018). The first line defensive grid of antioxidant enzyme ruled by metal ions in SAAE succeeds in nitric oxide accumulation and other consequent diarrheal damages. Contrarily, $\mathrm{Fe}^{2+}$ is essential for enzymes, involved in energy production, transport of oxygen in blood, and boosting of immune function. Besides that, $\mathrm{Zn}^{2+}$ is critical for 300 enzyme activities and essential for carbohydrate metabolism. Its antioxidant property helps in healing and regeneration of damaged tissues during diarrhea.

\section{In vivo antidiarrheal index}

In vivo antidiarrheal index of SAAE was observed in dose-dependent way (Fig. 4). The highest antidiarrheal index was keenly observed at the effective dose $300 \mathrm{mg} / \mathrm{kg}$. The

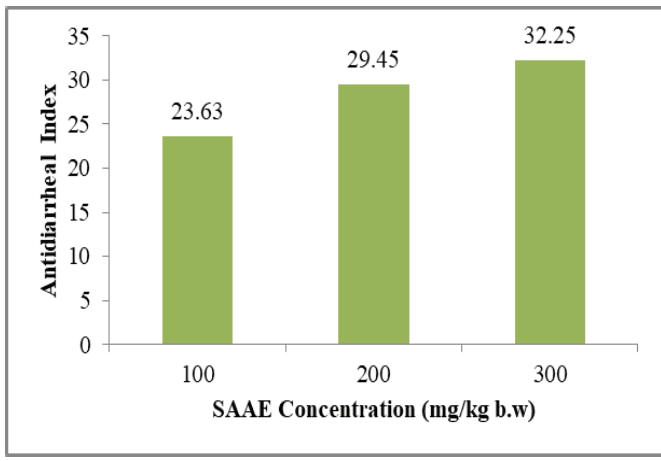

Figure 4. In vivo antidiarrheal index (ADI) of SAAE. Bark was reduced the overall symptoms of castor oil-induced diarrhea in dose-dependent manner.. nem. 

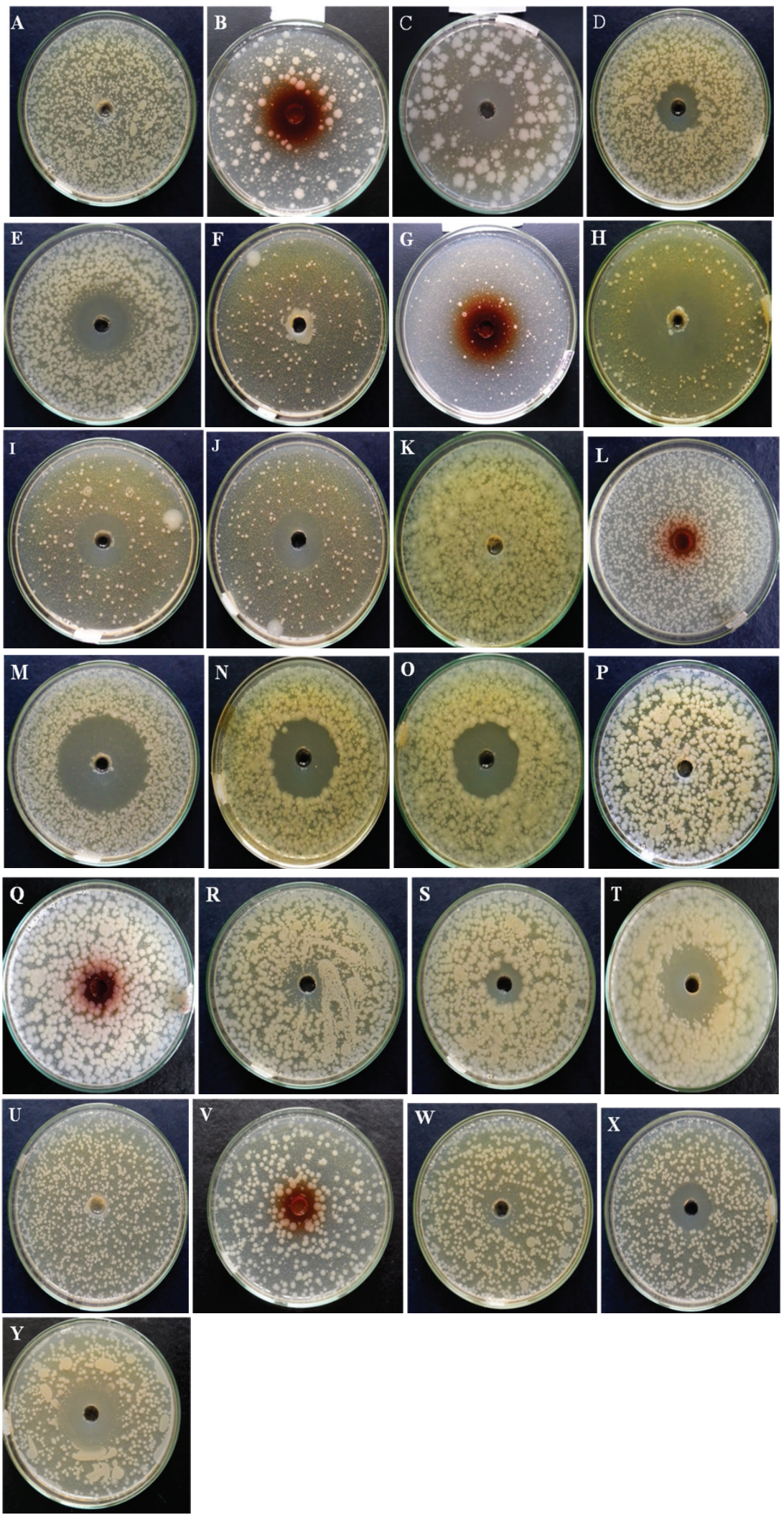

Figure 5. Antibacterial activity of SAAE against pathogen: Enterotoxigenic E. coli ETEC H10407 (A-E); A—control; B-SAAE (200 mg/ml); C—Co-Trimaxazole; D-Amphicillin; E-Streptomycin; Salmonella typhi (F-J) F-Control; G-SAAE (300 mg/ml); H-Co-Trimaxazole; I-Amphicillin; J-Streptomycin; Stephylococcus aureus (K-O) K-Control; L-SAAE (300 mg/ml); M-Co-Trimaxazole; N-Amphicillin; O—Streptomycin; Klebsiella pneumoniae (P-T) PControl; Q-SAAE (100 mg/ml); R-Co-Trimaxazole; S-Amphicillin; T—Streptomycin; Pseudomonas aureginosa (U-Y) U-Control; V—SAAE (100 mg/ml); W-CoTrimaxazole; X-Amphicillin; Y-Streptomycin. *CoTrimaxazole, Amphicillin and Streptomycin (1 mg/ml). 
antidiarrheal index (ADI) is a measure of a combined effect of the independent parameters of diarrhea such as purging frequency, onset of diarrheal stools, and intestinal motility. Accurate representation of ADI is useful specification in ranking an antidiarrheal agent (Adeyemi and Akindele, 2008; Brijesh et al., 2009; Mbagwu et al., 2008 ; Umer et al., 2013). The higher the ADI value, the more the effective against diarrhea.

\section{CONCLUSION}

Based on the above findings, the present study provides convincing evidence that SAAE possesses remarkable antibacterial and antidiarrheal activity. A noticeable presence of flavonoids, phenols, terpenoids, and micronutrients (ICP-OES sensitive method) in extract showed the protective effect and is rapid, long lasting, and statistically significant. It might be rightfully approachable formulations to provide better treatment against infectious diarrhea along with electrolyte therapy. However, further chemical and pharmacological studies are reasonably required to elucidate the precise mechanism.

\section{ACKNOWLEDGMENT}

The authors would like to thank Mr. Sandesh K Gowda Director, Niranthara Scientific Solutions, Bengaluru, Karnataka, for adequately providing the plant sample. The authors are would also like to thank the Department of P.G Studies and Research in Microbiology, Kuvempu University, Shankaraghatta, for providing the laboratory facilities.

\section{CONFLICT OF INTEREST}

Authors declare that there are no conflicts of interest.

\section{FINANCIAL SUPPORT AND SPONSORSHIP}

\section{None.}

\section{REFERENCES}

Adeyemi OO, Akindele AJ. Antidiarrhoeal activity of the ethyl acetate extract of Baphia nitida (Papilionaceae). J Ethnopharmacol, 2008; 116:407-12.

Alberts B, Johnson A, Lewis J, Morgan D, Raff M, Roberts. Molecular biology of the cell. Garland Science, New York, NY, 2002.

Almeida CE, Karnikowski MG, Foleto R, Baldisserotto B. Analysis of antidiarrhoeic effect of plants used in popular medicine. Rev Saude Publica, 1995; 29(6):428-33.

Aqil F, Khan SMA, Owais M, Ahmad I. Effect of certain bioactive plant extracts on clinical isolates of $\beta$-lactamase producing methicillin resistant Staphylococcus aureus. J Basic Microbiol, 2005; 45(2):106-14.

Arakha M, Pal S, Samantarrai D, Panigrahi TK, Mallick BC, Pramanik K, Mallick B, Jha S. Antimicrobial activity of iron oxide nanoparticle upon modulation of nanoparticle-bacteria interface. Sci Rep, $2015 ; 5: 1-12$

Arunlakshana O, Schild HO. Some quantitative uses of drug antagonists. Br J Pharmacol Chemother, 1959; 14:48-58.

Awad AB, Toczek J, Fink CS. Phytosterols decrease prostaglandin release in cultured P388D1/MAB macrophages. Prostaglandins Leukot Essent Fatty Acids, 2004; 70(6):511-20.

Banfi E, Scialino G, Bragadin CM. Development of a microdilution method to evaluate Mycobacterium tuberculosis drug susceptibility. J Antimicrob Chemother, 2003; 52:796-800.

Bennett JV, Brodie JL, Benner EJ, Kirby WMM. Simplified, accurate method for antibiotic assay of clinical specimens. Appl Microbiol, 1996; 14(2):170-7.
Bhutta Z, Black RE, Hidayat A, Penny M. Therapeutic effects of oral zinc in acute and persistent diarrhea in children in developing countries: pooled analysis of randomized controlled trials. Am J Clin Nutr, 2000; 72:1516-22.

Brijesh S, Daswani P, Tetali P, Antia N, Birdi T. Studies on the antidiarrhoeal activity of Aegle marmelos unripe fruit: validating its traditional usage. BMC Complement Altern Med, 2009; 47(9):1-12.

Brown JH, Taylor P. Muscarinic receptor agonists and antagonists. Goodman and Gilman's pharmacological basis of therapeutics. McGraw-Hill, New York, NY, $1996 .$.

Chandra M. Antimicrobial activity of medicinal plants against human pathogenic bacteria. Int J Biotechnol Biol Res, 2013; 4(7):653-58.

Degu A, Engidawork E, Shibeshi W. Evaluation of the antidiarrheal activity of the leaf extract of Croton macrostachyus Hocsht. ex Del. (Euphorbiaceae) in mice model. BMC Complement Altern Med, 2016; 16:379.

Dosso K, Nguessan BB, Bidie AP, Gnangoran BN, Méité S, Nguessan D. Antidiarrhoeal activity of an ethanol extract of the stem bark of Piliostigma reticulatum (Caesalpiniaceae) in rats. Afr J Tradit Complement Altern Med, 2011; 2(9):242-9.

Elena B, Giuditta S, Carlo MB. Development of a microdilution method to evaluate Mycobacterium tuberculosis drug susceptibility. J Antimicrob Chemother, 2003; 52:796-800.

Enzo PA. Phytochemicals from traditional medicinal plants used in the treatment of diarrhoea: modes of action and effects on intestinal function. Phytother Res, 2006; 20(9):717-24.

Favus MJ, Kathpalia SC, Coe FL. Kinetic characteristics of calcium absorption and secretion by rat colon. Am J Physiol, 1981; 240(5):G350-4.

Giannattasio A, Guarino A, Vecchio AL. Management of children with prolonged diarrhea. F1000 Res, 2016; 5:1-11.

Hamalainen M, Nieminen R, Asmawi MZ, Vuorela P, Vapaatalo $\mathrm{H}$, Moilanen E. Effects of flavonoids on prostaglandin E2 production and on COX-2 and mPGES-1 expressions in activated macrophages. Planta Med, 2011; 77(13):1504-11.

Ismail S, Asad M. Immunomodulatory activity of Acacia catechu. Indian J Physiol Pharmacol, 2009; 53(1):25-33.

Ighadaro OM, Akinolye OA. First line defence antioxidantssuperoxide dismutase (SOD), catalase (CAT) and glutathione peroxidase (GPX): their fundamental role in the entire antioxidant defence grid. Alexendria J Med, 2018; 287-293.

Kang CG, Hah DS, Kim CH, Kim YH, Euikyung Kim E, JongShu Kim JS. Evaluation of antimicrobial activity of the methanol extracts from 8 traditional medicinal plants. Toxicol Res, 2011; 27(1):31-6.

Khan AV, Ahmed QU, Shukla I, Khan AA. Antibacterial activity of leaves extracts of Trifolium alexandrinum Linn. against pathogenic bacteria causing tropical diseases. Asian Pac J Trop Biomed, 2012; 2(3):189-94.

Khan IA, McChesney JD, Burandt CL. Qualitative and quantitative high performance liquid chromatographic analysis of quassinoids in in Simaroubaceae plants. Phytochem Anal, 1996; 7(4):192200.

Kiela PR, Ghishan FK. Physiology of intestinal absorption and secretion. Best Pract Res Clin Gastroenterol, 2016; 30(2):145-59.

Kirchhoff P, Geibel JB. Role of calcium and other trace elements in the gastrointestinal physiology. World J Gastroenterol, 2006; 12(20):3229-36.

Lemire JA, Harrison JA, Turner RJ. Antimicrobial activities of metals: mechanisms, molecular targets and application. Nat Rev Microbiol, $2013 ; 11: 371-84$.

Maciel MA, Pinto AC, Arruda AC, Pamplona SG, Vanderlinde FA, Lapa AJ. Ethnopharmacology, phytochemistry and pharmacology: a successful combination in the study of Croton cajucara. J Ethnopharmacol, 2000; 70(1):41-55.

Maddison J, Page S, Church D. Small animal clinical pharmacology. W.B. Saunders, London, UK, 2002. 
Maranhão HML, Carlos FB, Vasconcelos CFB, Rolim LA, Neto PJR, Silva Neto JC. Hepatoprotective effect of the aqueous extract of simarouba amara (aublet) (simaroubaceae) stem bark against carbon tetrachloride $\left(\mathrm{ccl}_{4}\right)$-induced hepatic damage in rats. Mole, 2014a; 19:1773546.

Maranhão HML, Rolim LA, Caldas GFR, Silva-Neto JC, Wanderley AG. Gastroprotective effects of the aqueous extract of Simarouba amara (Aublet) (Simaroubaceae) stem bark on experimentally induced gastric ulcers in rodents. Int Res J Pharm App Sci, 2014b; 4(2):58-66.

Maranhão HML, Vasconcelos CFB, Rolim LA, Costa-Silva JH, Silva Neto JC, Wanderley AG. Acute and subacute toxicities of the aqueous extract of Simarouba amara Aublet stem bark. Int J Pharm Sci Res, 2014c; 5(12):5151-62

Mbagwu HO, Adeyemi OO. Anti-diarrhoeal activity of the aqueous extract of Mezoneuron benthamianum Baill (Caesalpinaceae). J Ethnopharmacol, 2008; 116:16-20.

Medina FS, Galvez J, Gonzalez M, Zarzuelo A, Barrett KE. Effects of quercetin on epithelial chloride secretion. Life Sci, 1997; 61(20):2049-55.

Nemeth J, Oesch G, Kuster SP. Bacteriostatic versus bactericidal antibiotics for patients with serious bacterial infections: systematic review and meta-analysis, J Antimicrob Chemother, 2015; 70:382-95.

Ngo-Teke G, Kulate JR, Kuete V, Teponno RB, Tapondjou LA, Vllarem G. Antidiarrhoeal activity of extract and compound from Trilepisium madagascariense stem bark. Ind J Pharma, 2010; 42(3):157-63.

Polonsky J, Varon Z, Jacquemin H, Petitt GR. The isolation and structure of 13,18-dehydroglaucarubinone, a new antineoplastic quassinoid from Simarouba amara. Expernetia, 1978; 34(9):1122-3.

Qing-hua Y, Li Y, Qing W, MaXiao-qin. Determination of major and trace elements in six herbal drugs for relieving heat and toxicity by ICPAES with microwave digestion. J Saudi Chem Soc, 2012; 16(3):287-90.

Raj PY, Deepa K, Reddy MA, Reddeppa M, Rani ST. Evaluation of trace elements in some medicinal plants: Jatropha, Albizia, Azardicta indica and Datura plants. Eur J Pharm Med Res, 2017; 4(7) 455-65. Satyajit S, Lutfun N. "Turmeric: the genus Curcuma" bioactivity of turmeric. CRC Press, Boca Raton, FL, pp 56-60, 2007.

Shao H, Bian CM. Determination of the content of trace elements and rates of transference in seven traditional Chinese medicines. Guangdong Trace Elements Sci, 2002; 9(11):51-4.

Sharma S, Lakshmi KS, Rajesh. T. Evaluation of antidiarrhoeal potentials of ethanolic extract of leaves of Holoptelea integrifolia in mice model. Int J PharmTech Res, 2009; 1(3):832-6.

Taylor L. Technical Data Report for Simarouba; Simarouba amara. Herbal Secrets of the Rainforest. Sage Press Inc, Austin, TX, vol. 2, pp 1-20, 2003
Tripathi KD. Essentials of medical pharmacology. Jaypeeb Brothers Medicals Publishers (P) Ltd, New Delhi, India

Tunaru S, Althoff TF, Nüsing RM, Diener M, Offermanns $\mathrm{S}$. Castor oil induces laxation and uterus contraction via ricinoleic acid activating prostaglandin $\mathrm{EP}_{3}$ receptors. PNAS, 2012; 109(23):9179-84.

Tyagi P, Singh M, Kumari H, Kumari A, Mukhopadhyay K. Bactericidal activity of Curcumin I is associated with damaging of bacterial membrane, PLoS One, 2015; 10(3):1-15.

Umer S, Tekewe A, Kebede N. Antidiarrhoeal and antimicrobial activity of Calpurnia aurea leaf extract. BMC Complement Altern Med, 2013; 13(21):1-5.

Valle DL Jr. Cabrera EC, Puzon JJM, Rivera WL. Antimicrobial activities of methanol, ethanol and supercritical $\mathrm{CO}_{2}$ extracts of Philippine piper betle on clinical isolates of gram positive and gram negative bacteria with transferable multiple drug resistance, PLoS One, 2015; 11(1):1-14.

Weaver AJJ, Shepard JB, Wilkinson RA, Watkins RL, Walton SK, Radke. Antibacterial activity of THAM trisphenylguanide against methicillin-resistant Staphylococcus aureus. PLoS One, 2014; 9(5):1-9.

Wright CW, O’Neill MJ, Phillipson D, Warhurst DC. Use of microdilution to assess in vitro antiamoebic activities of bruceajavanica fruits, Simarouba amara stem, and a number of quassinoids. Antimicrob Agents Chemother, 1988; 32(11):1725-9.

Xie Y, Yang L. Calcium and magnesium ions are membraneactive against stationary-phase Staphylococcus aureus with high specificity. Sci Rep, 2016; 6:1-8.

Yadav AK, Tangpu V. Antidiarrheal activity of Lithocarpus dealbata and Urena lobata extracts: therapeutic implications. Pharm Biol, 2007; 45(3):223-9.

Zeng B, Chen Q, Ju M. Trace elements associated with the analysis of the efficacy of traditional Chinese medicine. Lishizhen Med Materia Med Res, 2001; 12(7):658-61.

How to cite this article:

Hegde V, Nagaraj N, Gowda SK, Thippeswamy NB. Antibacterial and antidiarrheal activity of Simarouba amara (Aubl.) bark. J Appl Pharm Sci, 2019; 9(05):088-096. 